\title{
Preparation of uranium(III) in a molten chloride salt: a redox mechanistic study
}

\author{
Hugues Lambert ${ }^{1,2}$ (D) Timothy Kerry ${ }^{1,3}$ (1) $\cdot$ Clint A. Sharrad ${ }^{1}$ (I)
}

Received: 31 March 2018/Published online: 28 June 2018

(C) The Author(s) 2018

\begin{abstract}
The most advanced methodology for the pyroprocessing of spent nuclear fuel is the electrorefining of uranium metal in $\mathrm{LiCl}-\mathrm{KCl}$ eutectic, in which uranium is solubilized as $\mathrm{U}(\mathrm{III})$. The production of $\mathrm{U}(\mathrm{III})$ in $\mathrm{LiCl}-\mathrm{KCl}$ eutectic by the chlorination of uranium metal using $\mathrm{BiCl}_{3}$ has been performed for research purposes. In this work, this reaction was studied in-situ by visual observation, electronic absorption spectroscopy and electrochemistry at $450{ }^{\circ} \mathrm{C}$. The most likely mechanism has been determined to involve the initial direct oxidation of uranium metal by Bi(III) to U(IV). The dissolved U(IV) then reacts with unreacted uranium metal to form U(III).
\end{abstract}

Keywords Uranium(III) $\cdot$ Molten salts $\cdot$ Electronic absorption spectroscopy $\cdot$ Cyclic voltammetry $\cdot$ Open circuit potential

\section{Introduction}

With a renewed interest in pyrochemical technology for spent nuclear fuel treatment [1-3] and molten salt reactor reprocessing schemes $[4,5]$, fundamental studies in molten salt chemistry are becoming key to understanding engineering scale experimentation and to develop process modelling [6, 7]. Pyroprocessing is a possible alternative to the more traditional hydrometallurgical route for spent nuclear fuel treatment, especially for some GEN IV fuels such as nitrides and metallic fuels. Its main advantages are

Hugues Lambert and Clint A. Sharrad are joint first authors.

Clint A. Sharrad

clint.a.sharrad@manchester.ac.uk

Hugues Lambert

Hugues.LAMBERT@1hoist.com

Timothy Kerry

timothy.kerry@manchester.ac.uk

1 School of Chemical Engineering and Analytical Science, The University of Manchester, Oxford Road,

Manchester M13 9PL, UK

2 Present Address: Lhoist Recherche et Développement, Business Innovation Cente, 31, rue de l'Industrie, 1400 Nivelles, Belgium

3 Present Address: Department of Materials Science and Engineering, Delft University of Technology, Mekelweg 2, 2628 CD Delft, The Netherlands the radiation resistance of molten salt and minimum criticality risk enabling a more compact process. In the $1980 \mathrm{~s}$ Argonne National Laboratory developed a process at pilot scale to treat spent metallic fuel from its EBR-II reactor as part of the Integral Fast Reactor project [8]. The core of the reprocessing scheme is the electrotransport of uranium via anodic dissolution in a molten $\mathrm{LiCl}-\mathrm{KCl}-\mathrm{UCl}_{3}(5 \mathrm{wt} \% \mathrm{U})$ salt at $500{ }^{\circ} \mathrm{C}$. During this operation the dissolved uranium is in contact with uranium metal. The presence of uranium metal will control the redox potential of the salt and the dissolved uranium will be present as U(III). While most chemical elements can be purchased as dry chlorides, it is not the case for uranium. In order to study this system it is important to established a reproducible route to prepare $\mathrm{LiCl}-\mathrm{KCl}$ eutectic (LKE) containing U(III). The most common forms of uranium are as nitrates, oxides and metal, all in oxidation states other than +III. Uranium metal can be used for the production of dry chloride in different ways, but most of those methods would use corrosive gases and/or produce harmful volatiles [9-11]. It is important to underline the sensitivity of uranium chlorides towards oxygen and water [12]. Therefore, classical synthetic production routes producing powders with high surface area [13] are ill-suited for facilities where it is difficult to ensure an inert atmosphere at all times. The oxidation of uranium metal by metal chlorides is a preferred route for the production of chloride salt containing U(III). It also enables the direct dissolution of uranium 
chloride in the salt. Once quenched, the dissolved U(III) chloride is relatively well-protected from oxidation by air/moisture from the atmosphere. $\mathrm{PbCl}_{2}$ was proposed for the synthesis of U(III) in LKE as early as 1959 [14]. But historically, $\mathrm{CdCl}_{2}$ has been used in the Mark IV electrorefiner at the Idaho National Laboratory (INL) for direct production of uranium trichloride in molten $\operatorname{LKE}[15,16]$. Its two main drawbacks are the presence of cadmium, which raises toxicity concerns, and difficulties in removing any remaining $\mathrm{CdCl}_{2}$ at the end of the reaction by volatilization. To overcome those difficulties, INL has been studying alternative chlorinating agents such as $\mathrm{CuCl}_{2}$ [17]. Unfortunately the formation of $\mathrm{UCl}_{4}$ as an intermediary product makes this reaction incompatible for industrial processes as $\mathrm{UCl}_{4}$ reacts with iron to form $\mathrm{FeCl}_{2}$. Furthermore, the low vapour pressure of $\mathrm{CuCl}_{2}$ at the typical temperatures required makes it difficult to apply in the laboratory. In the early 2000 s, the use of $\mathrm{BiCl}_{3}$ was proposed for the oxidation of plutonium metal in LKE at laboratory scales [18]. This route is efficient, convenient and the only two contaminants are bismuth metal, which will be inert at the bottom of the reaction vessel and nonreacted $\mathrm{BiCl}_{3}$. Another reason for the use of $\mathrm{BiCl}_{3}$ in laboratory preparations of actinide(III) chlorides is the fact that its vapour pressure is higher than that for $\mathrm{CdCl}_{2}$, as shown in Fig. 1, and is therefore much easier to volatize at the end of the reaction. This synthetic approach has also been successfully applied to the production of $\mathrm{UCl}_{3}$ and $\mathrm{NpCl}_{3}[19,20]$.

The calculated Gibb's energy of reactions likely to occur from reacting $\mathrm{U}$ metal with $\mathrm{BiCl}_{3}$ are presented below (Eqs. 1-4) [21]. The direct formation of $\mathrm{UCl}_{4}$ appears to be

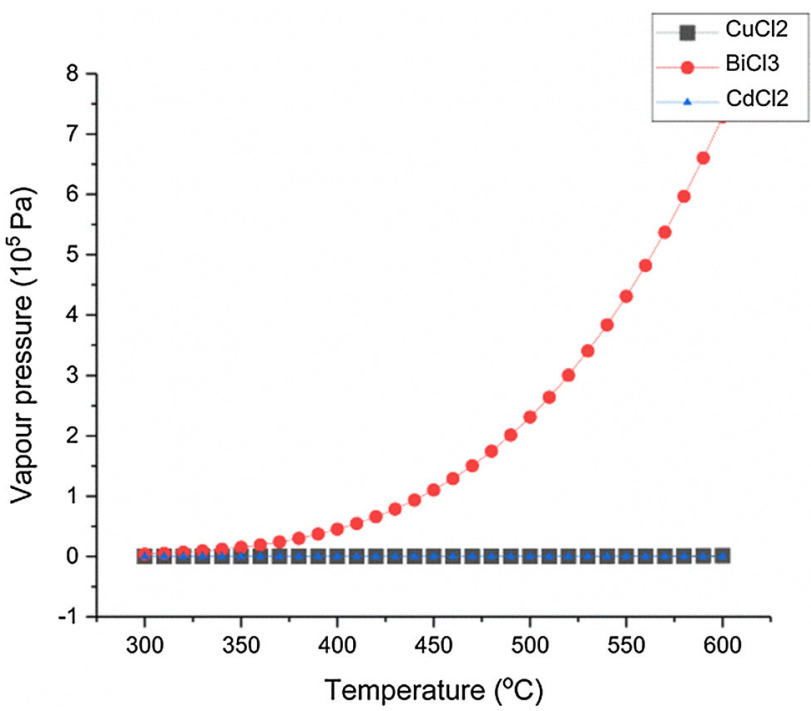

Fig. 1 Plot of vapor pressure vs temperature for different chlorinating agents; black: $\mathrm{CuCl}_{2}$; red: $\mathrm{BiCl}_{3}$; blue: $\mathrm{CdCl}_{2}$. Calculated from the HSC Thermochemical Database. (Color figure online) favoured but these calculations are limited as the exact molecular species in the solution melts are not considered.

$$
\begin{aligned}
\mathrm{U}_{\text {metal }}+\mathrm{BiCl}_{3} & \rightarrow \mathrm{UCl}_{3}+\mathrm{Bi}_{\text {metal }} \\
\underset{r}{\Delta} G\left(450{ }^{\circ} \mathrm{C}\right) & =-471 \mathrm{~kJ} \mathrm{~mol}^{-1} \\
\mathrm{U}_{\text {metal }}+\frac{4}{3} \mathrm{BiCl}_{3} & \rightarrow \mathrm{UCl}_{4}+\frac{4}{3} \mathrm{Bi}_{\text {metal }} \\
\underset{r}{\Delta} G\left(450{ }^{\circ} \mathrm{C}\right) & =-492 \mathrm{~kJ} \mathrm{~mol}^{-1} \\
\mathrm{UCl}_{3}+\frac{1}{3} \mathrm{BiCl}_{3} & \rightarrow \mathrm{UCl}_{4}+\frac{1}{3} \mathrm{Bi}_{\text {metal }} \\
{ }_{r} G\left(450{ }^{\circ} \mathrm{C}\right) & =-21 \mathrm{~kJ} \mathrm{~mol}^{-1} \\
\mathrm{U}_{\text {metal }}+3 \mathrm{UCl}_{4} & \rightarrow 4 \mathrm{UCl}_{3} \\
\underset{r}{\Delta} G\left(450{ }^{\circ} \mathrm{C}\right) & =-409 \mathrm{~kJ} \mathrm{~mol}^{-1}
\end{aligned}
$$

A similar method has been used to produce U(III) in fluoride melts [22]. This work presented here extensively explores the reaction of $\mathrm{U}$ metal with $\mathrm{BiCl}_{3}$ in $\mathrm{LiCl}-\mathrm{KCl}$ eutectic at $450{ }^{\circ} \mathrm{C}$ using electrochemical and spectroscopic techniques to probe the redox mechanistic behavior of this reaction, building upon previous work by Bae et al. [23], in order to ensure the control and efficiency of this key reaction for the production of $\mathrm{U}(\mathrm{III})$ as the research of actinide behavior in molten salt systems expands with advancing nuclear technologies.

\section{Experimental}

\section{Apparatus and electrochemistry}

The furnace and the spectroscopic cell used in these studies have been described elsewhere [8]. A three electrode system was used for all electrochemical studies, unless otherwise stated, composed of two tungsten rods $(2 \mathrm{~mm}$ diameter) as working and counter electrodes and a reference electrode of $\mathrm{Ag} / \mathrm{AgCl}$ housed in mullite. In order to fit the electrodes in the cell, an in-house PTFE holder was designed with four insertion holes. The holes were used to house the three electrode system and an additional tube used, if necessary, to insert material, bubble gases and/or extract the melt for quenching. All electrochemical experiments were controlled using a PGSTAT 101 potentiostat from Metrohm. All potentials are reported vs Ag/ $\mathrm{AgCl}$ (1.5 wt\% in LKE).

\section{Electronic absorption spectroscopy}

In-situ high temperature electronic absorption spectroscopy of the melts was performed using the set-up displayed in the schematic diagram shown in Fig. 2. The light from a tungsten halogen lamp source is directed to the furnace via 


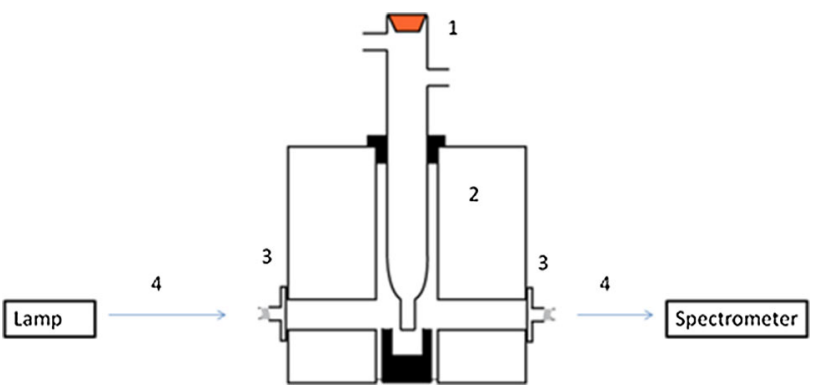

Fig. 2 Schematic diagram of the spectroscopic set-up; 1: cell; 2: furnace; 3: collimator; 4: fiber optic

fiber-optics. Two types of optical fiber were used depending on the application:

- Solarized UV-vis fiber optics from AVANTES for use from 180 to $900 \mathrm{~nm}$.

- Broadband vis-NIR fibre optics from AVANTES for use from 500 to $1600 \mathrm{~nm}$.

The fiber is connected to a collimator that ensures the beam of light is directed through the cell. The light is collected back from a similar collimator into the fibre optic which is connected to the spectrometer. Depending on experimental requirements, three spectrometers were utilised:

- UV detector (S1), AVASPEC-UL2048L, working from 180 to $640 \mathrm{~nm}$.

- Vis detector (S2), AVASPEC-UL2048XL-RS, working from 500 to $1100 \mathrm{~nm}$.

- NIR detector (S3), AVASPEC-NiR256 1.7, working from 950 to $1600 \mathrm{~nm}$.

This enabled the study of the electromagnetic spectrum from 180 to $1600 \mathrm{~nm}$.

\section{Salt preparation}

$\mathrm{LiCl}$ (Alfa Aesar, 99\% min) and $\mathrm{KCl}$ (Sigma, 99\% min) were mixed in $45-55 \mathrm{wt} \%$ ratios and added to an alumina crucible. The powder was dried, at $140{ }^{\circ} \mathrm{C}$, under vacuum overnight in a tube furnace. The temperature of the tube furnace containing the salt mixture was raised to $450{ }^{\circ} \mathrm{C}$ and held for three hours under argon. The purity of the salt was determined by cyclic voltammetry, by assessing the oxygen and/or hydroxyl anion content in the salt using a tungsten electrode. If necessary, the salt was electrolyzed [24] using a vitreous carbon rod as a working electrode, a tungsten rod as the counter electrode and $\mathrm{Ag} / \mathrm{AgCl}(1.5$ $\mathrm{wt} \%$ in LKE) sheeted in mullite as a reference electrode, to remove any transition metal impurities and remaining water/oxygen content in the salt. The molten salt was then quenched in a quartz tube and kept under an argon atmosphere before use.
Reagent preparation

$\mathrm{BiCl}_{3}$ (anhydrous beads $99.999 \%$ Sigma) was used as received. The uranium metal was obtained from the Centre for Radiochemistry Research (University of Manchester) stocks. The uranium metal was contacted with concentrated nitric acid $(\sim 10 \mathrm{M})$ in accordance with previously described procedures to remove the corroded surface layer [25]. The cleaned metal was immediately rinsed in distilled water followed by acetone. The metal sample was patted dry upon paper towel and immediately added to the cell, where any remaining moisture/acetone was removed under vacuum.

\section{Synthesis of $\mathrm{U}(\mathrm{III})$ in $\mathrm{LiCl}-\mathrm{KCl}$ eutectic}

At room temperature, the dried salt $(16.70 \mathrm{~g})$ and the uranium metal $(0.30 \mathrm{~g})$ were further dried under vacuum in the quartz cell at $140{ }^{\circ} \mathrm{C}$ for two hours, using the tube furnace. The electrodes were inserted into the cell, but held above the salt mixture, and the furnace temperature was then raised until the salt temperature was $450{ }^{\circ} \mathrm{C}$. Once the salt was molten, the electrodes were lowered in the liquid salt and the absorption spectrum of the melted salt was acquired. $\mathrm{BiCl}_{3}(0.30 \mathrm{~g})$ was directly added to the liquid melt, using the insertion tube. The reaction was left to evolve for eight hours after which, argon was bubbled in the solution in order to bring the reaction to completion. The open circuit potential (OCP) of the salt was recorded from the point the $\mathrm{BiCl}_{3}$ addition was made. Cyclic voltammetry was also performed at regular time intervals in order to follow the salt composition. The reaction was monitored using absorption spectroscopy and observations were made from visual inspection of the molten salt mixture in the quartz cell. This experiment was performed multiple times and negligible differences were observed for the overall trends in results obtained using both spectroscopic and electrochemical techniques. However, the observed kinetics of this reaction did vary between experimental runs.

\section{Results and discussion}

\section{Visual observations}

Contact of the salt with $\mathrm{U}$ metal without any other reagents showed the salt remained transparent indicating that no reaction had taken place. As $\mathrm{BiCl}_{3}$ was added, no immediate change was noted. Typically after approximately one hour, the salt was a green colour, as shown in Fig. 3a, b, indicating the presence of $\mathrm{U}(\mathrm{IV})$ in solution [9]. The 

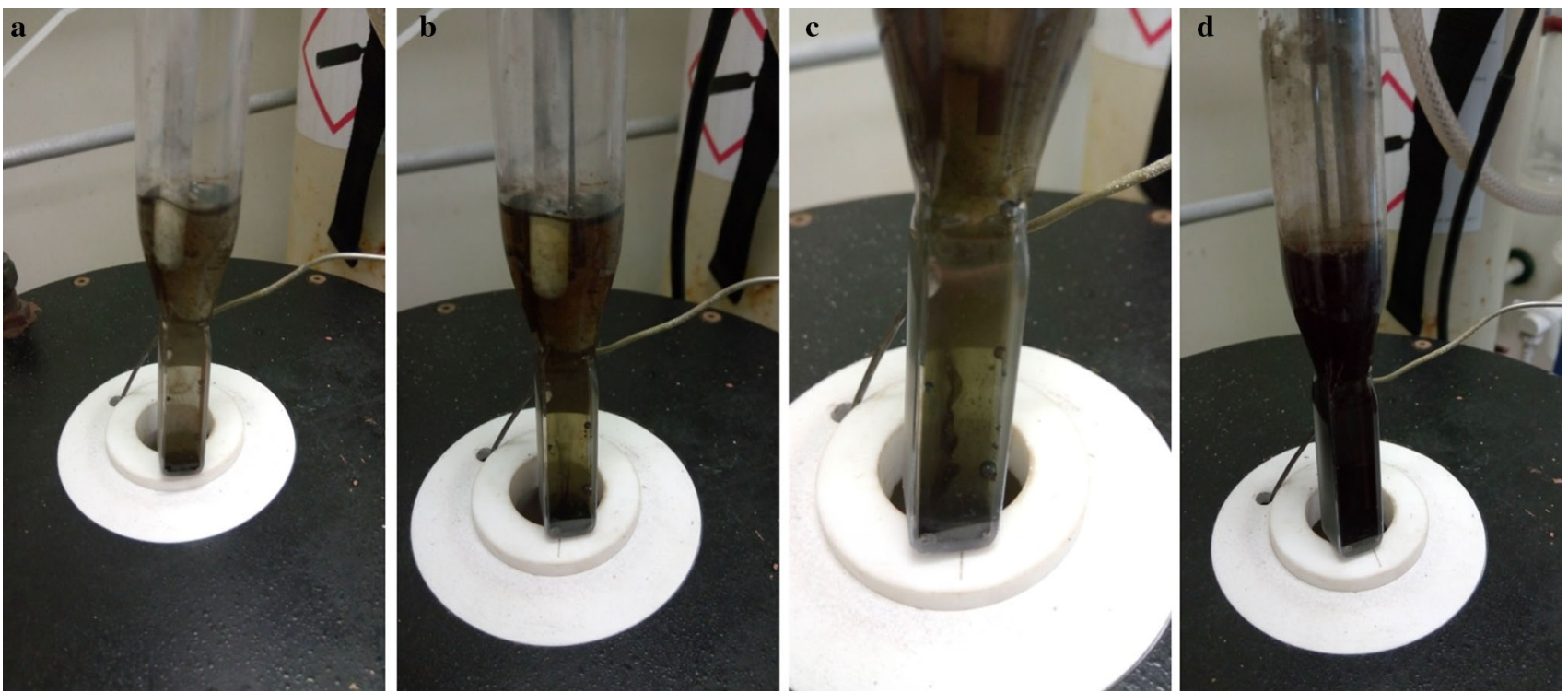

Fig. 3 Pictures showing an example of the reaction progression of $\mathrm{U}$ metal with $\mathrm{BiCl}_{3}$ in $\mathrm{LiCl}-\mathrm{KCl}$ eutectic at $450{ }^{\circ} \mathrm{C}$ over time; a 135 min; b $380 \mathrm{~min}$; c $470 \mathrm{~min}$; d $500 \mathrm{~min}$

increasing presence of a metal pool at the bottom of the cell was observed as the reaction continued. As the green coloration of the salt became more intense, the presence of a "smog chimney" through the melt was noted. The smog appeared to be emanating from the still reacting uranium metal sample located at the bottom of the cell. This dark "smog" is most likely due to the formation of U(III) which is known to be a very intense purple colour in chloride melts [9]. As the reaction proceeded, the intensity of this "smog" increased as shown in Fig. 3b, c, but still was observed in a "chimney" form suggesting that as the U(III) diffused into the bulk of the melt it was being converted to U(IV). Typically after approximately four hours of the reaction, the metal pool at the bottom of the cell was several millimetres thick. The exact timings of these observations did vary between experimental runs which we attribute to a number of factors such as different surface area: volume ratios of the uranium metal used in the reaction, differences in the quality of the "cleaned" uranium metal surface and avoiding a mixed reaction system. However, the order and nature of observations made during the progression of this reaction were consistent across experiments. Subsequent thorough mixing of the reaction solution by the bubbling of argon resulted in the salt becoming the deep-purple colour typical for U(III) as shown in Fig. 3d [9].

\section{Electronic absorption spectroscopy}

In-situ electronic absorption spectra of the molten salt were acquired employing a spectroscopic system similar to those used previously to acquire absorption spectra of high temperature melts $[9,26,27]$. The incoming light beam was positioned $\sim 1 \mathrm{~cm}$ above the uranium metal sample in order to attempt to identify any semi long-lived intermediate species in the melt during the reaction, but sufficiently far away from the metal sample to avoid light scattering from the Bi metal that formed. Spectra were obtained at various time intervals as the reaction of $U$ metal with $\mathrm{Bi}(\mathrm{III})$ proceeded. The relatively close proximity of the beam position to the uranium metal sample was chosen in order to possibly identify the formation of any intermediary products from this reaction. Immediately after the addition of $\mathrm{BiCl}_{3}$, a peak appears in the UV region and a saturated band can be observed up to $420 \mathrm{~nm}$, which is concordant with the dissolution of $\mathrm{Bi}^{3+}$ in chloride media $[28,29]$. During the initial stages of the reaction, spectra were recorded from 180 to $640 \mathrm{~nm}$, using detector S1, in order probe for the intensely absorbing U(III) $\mathrm{f} \rightarrow \mathrm{d}$ transitions at 458 and $555 \mathrm{~nm}$ [30]. As shown in Fig. 4, none of the characteristic U(III) peaks appeared during the first 60 min after $\mathrm{BiCl}_{3}$ was added to the melt for this experiment. However, peaks were observed at 460, 561 and $604 \mathrm{~nm}$ which are characteristic of U(IV) in chloride melts [30], and have been observed in previously studies reactions of $\mathrm{U}$ metal with $\mathrm{BiCl}_{3}$ in $\mathrm{LiCl}-\mathrm{KCl}$ eutectic melts. After approximately one hour, the detector S2 was connected in order to follow the evolution of the spectra in the visible-nIR region from 500 to $1025 \mathrm{~nm}$ for the remainder of the reaction. This enabled the following of U(IV) formation through its most intense absorption peak at $670 \mathrm{~nm}$ [8]. This is shown in Fig. 5. Despite the visual observation of a "smog chimney" in the melt emanating from the reacting $\mathrm{U}$ metal sample most likely due to the formation 


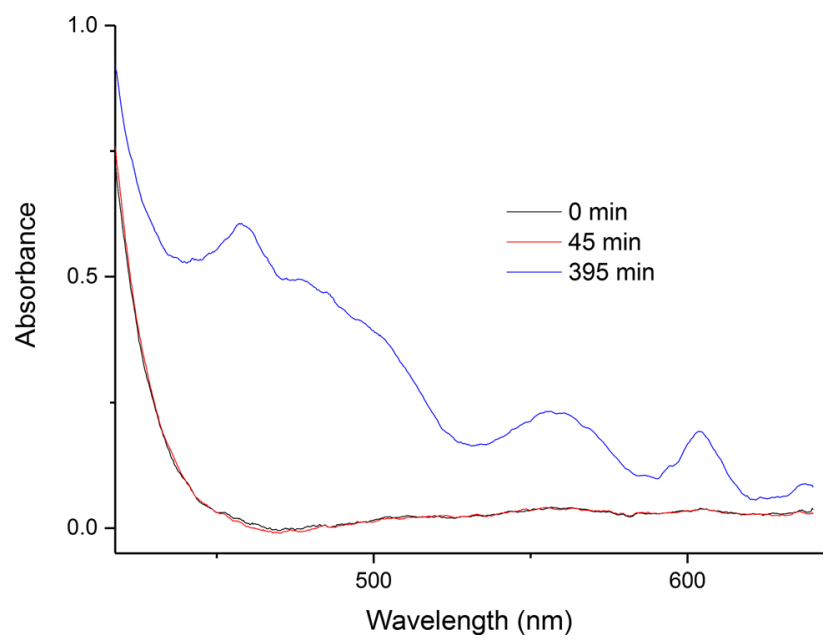

Fig. 4 Electronic absorption spectra of a reaction of $U$ metal with $\mathrm{BiCl}_{3}$ in $\mathrm{LiCl}-\mathrm{KCl}$ eutectic salt at $450{ }^{\circ} \mathrm{C}$. Evolution of the spectra in the $400-640 \mathrm{~nm}$ region was measured using detector S1. Times are indicative of the reaction progression for this specific experimental run

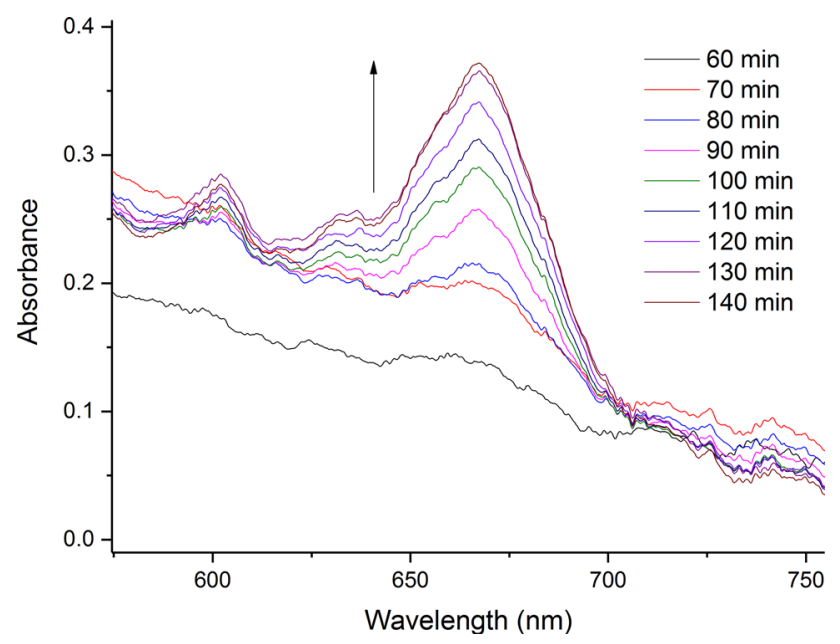

Fig. 5 Electronic absorption spectra of a reaction of $U$ metal with $\mathrm{BiCl}_{3}$ in $\mathrm{LiCl}-\mathrm{KCl}$ eutectic salt at $450{ }^{\circ} \mathrm{C}$. Evolution of the spectra in the $550-800 \mathrm{~nm}$ region was measured using detector $\mathrm{S} 2$. Times are indicative of the reaction progression for this specific experimental run

of U(III), no evidence of U(III) formation was observed in the spectra acquired while the melt was not mixed.

Figure 6 shows the evolution of the spectra from a reaction of the remaining $\mathrm{U}$ metal with the dissolved $\mathrm{UCl}_{4}$ in $\mathrm{LiCl}-\mathrm{KCl}$ eutectic at $450{ }^{\circ} \mathrm{C}$. The spectra evolves from a characteristic U(IV) profile towards that of U(III). The U(III) peak at $899 \mathrm{~nm}$ increases in intensity.

After the bubbling of argon, the spectroscopic profile became saturated across the entire UV-visible region of the spectrum as is expected for high U(III) concentrations [27]. Consequently, a quartz rod, $6 \mathrm{~mm}$ diameter, was inserted into the cell in order to reduce the solution pathlength. This

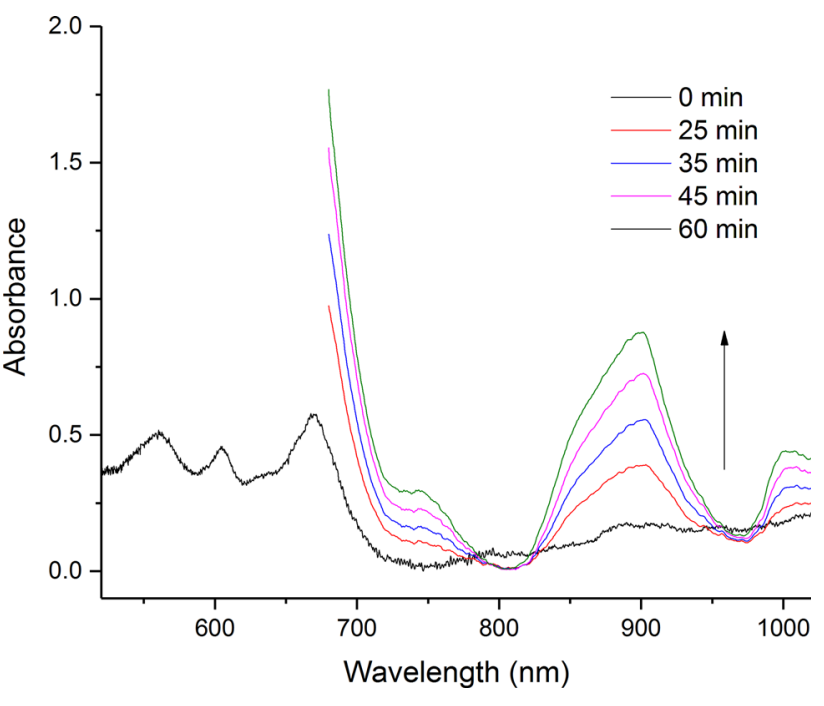

Fig. 6 Electronic absorption spectra of the reaction of $U$ metal in contact with $\mathrm{U}(\mathrm{IV})$ during the overall reaction of $\mathrm{U}$ metal with $\mathrm{BiCl}_{3}$ in $\mathrm{LiCl}-\mathrm{KCl}$ eutectic at $450{ }^{\circ} \mathrm{C}$. Times are indicative of the reaction progression for this specific experimental run

produced the spectrum shown in Fig. 7. Even with a quartz rod in the cell, the region below $700 \mathrm{~nm}$ is saturated but a peak is identified at $899 \mathrm{~nm}$ which is characteristic of U(III) [27, 31, 32].

\section{Electrochemistry}

Before adding $\mathrm{BiCl}_{3}$, the purity of the salt was confirmed by cyclic voltammetry (CV) with no peak observed within the electrochemical window of the salt (Fig. 8). Figure 9 shows the increase in the Open Circuit Potential (OCP) after the $\mathrm{BiCl}_{3}$ addition, with time zero corresponding to the start of the measurement and the $\mathrm{BiCl}_{3}$ was added on

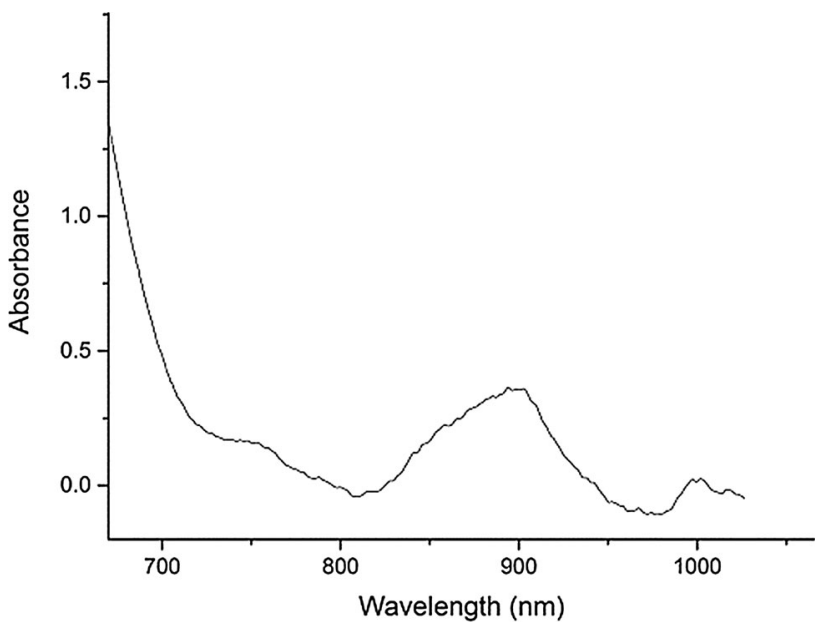

Fig. 7 Electronic absorption spectrum of the reaction mixture of $\mathrm{U}$ metal with $\mathrm{BiCl}_{3}$ in $\mathrm{LiCl}-\mathrm{KCl}$ eutectic at $450{ }^{\circ} \mathrm{C}$ after agitating the melt with Ar gas bubbling. The spectrum was measured with a quartz rod inserted in the cell using the spectrometer S2 


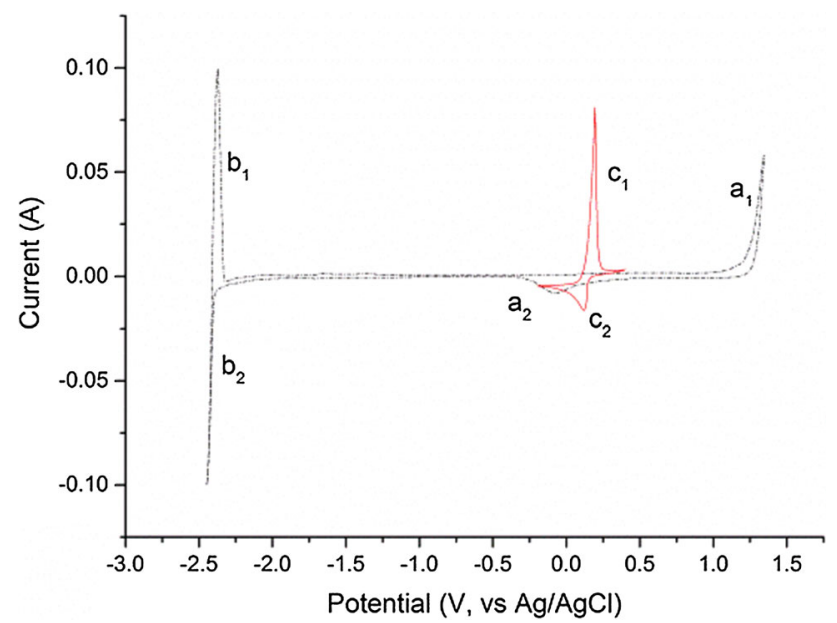

Fig. 8 Cyclic voltammograms of clean LKE salt (dashed black line; Assigned peaks-a1: $\mathrm{Cl}^{-} \rightarrow{ }^{1 / 2} \mathrm{Cl}_{2}+\mathrm{e}^{-} ; \mathrm{a} 2: 1 / 2 \mathrm{Cl}_{2}+\mathrm{e}^{-} \rightarrow \mathrm{Cl}^{-} ; \mathrm{b} 1:$ $\left.\mathrm{Li} \rightarrow \mathrm{Li}^{+}+\mathrm{e}^{-} ; \mathrm{b} 2: \mathrm{Li}^{+}+\mathrm{e}^{-} \rightarrow \mathrm{Li}\right)$ and $\mathrm{BiCl}_{3}(0.30 \mathrm{~g})$ added to LKE (16.70 g) one hour after addition (red line; Assigned peaks- $-\mathrm{c}_{1}$ : $\left.\mathrm{Bi} \rightarrow \mathrm{Bi}^{3+}+3 \mathrm{e}^{-} ; \quad \mathrm{c}_{2}: \quad \mathrm{Bi}^{3+}+3 \mathrm{e}^{-} \rightarrow \mathrm{Bi}\right) \quad\left\{\mathrm{T}=450{ }^{\circ} \mathrm{C} ; \quad\right.$ Scan rate $=0.1 \mathrm{~V} \mathrm{~s}^{-1}$; Working electrode: $\mathrm{W} \operatorname{rod}\left(\mathrm{S}=3 \times 10^{-4} \mathrm{~cm}^{2}\right)$; Counter electrode: W rod; Reference electrode: $\mathrm{Ag} / \mathrm{AgCl}$ (1.5 wt $\%$ in LKE)\}. (Color figure online)

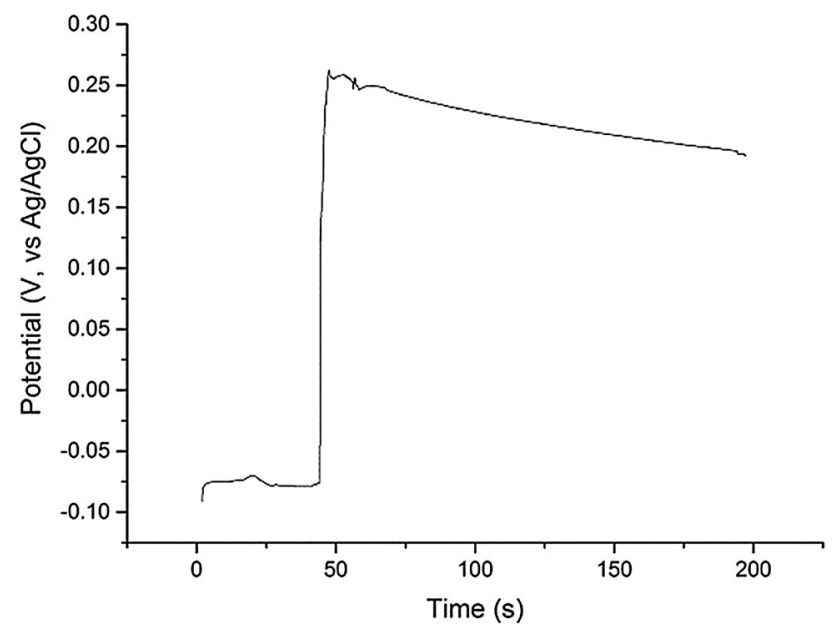

Fig. 9 Plot of Open Circuit Potential (vs $\mathrm{Ag} / \mathrm{AgCl}$ ) from $\mathrm{LiCl}-\mathrm{KCl}$ eutectic at $450{ }^{\circ} \mathrm{C}$ with $\mathrm{U}$ metal after $\mathrm{BiCl}_{3}$ addition (at $\mathrm{t} \sim 45 \mathrm{~s}$ ) with respect to time

the top of cell 30-60 s after the OCP started to be recorded. The red curve in Fig. 8 is a cyclic voltammogram recorded one hour after the addition of $\mathrm{BiCl}_{3}$ which shows the presence of an additional peak at $0.15 \mathrm{~V}$ ( $\mathrm{vs} \mathrm{Ag} / \mathrm{AgCl}$ ), which is concordant with the $\mathrm{Bi} / \mathrm{Bi}^{3+}$ couple in $\mathrm{LiCl}-\mathrm{KCl}$ eutectic [23, 33]. The boiling point of $\mathrm{BiCl}_{3}\left(447{ }^{\circ} \mathrm{C}\right)$ is lower than the temperature employed in these studies so it was important to verify the stability of $\mathrm{Bi}(\mathrm{III})$ in the melt. Indeed in our studies we have observed that $\mathrm{BiCl}_{3}$ remains solubilised in molten $\mathrm{LiCl}-\mathrm{KCl}$ eutectic over long time periods $(\sim 10 \mathrm{~h})$ for temperatures up to $500{ }^{\circ} \mathrm{C}$. Volkov et al. [28] have shown by absorption spectroscopy that
$\mathrm{BiCl}_{3}$ is dissolved as $\mathrm{BiCl}_{4}{ }^{-}$in $\mathrm{LiCl}-\mathrm{KCl}$ eutectic explaining its stability. After the sudden increase of the OCP in the melt, with the addition of $\mathrm{BiCl}_{3}$, the OCP then steadily decreases reflecting a decrease in the $\mathrm{Bi}(\mathrm{III})$ concentration in the melt either as the reaction with $U$ metal proceeded, or through loss by volatilization. The latter possibility is unlikely as no condensation of any solid material was observed anywhere in the cell during the reaction, especially parts of the cell protruding from the furnace which would be at temperatures substantially lower than $447^{\circ} \mathrm{C}$.

Several minutes after the addition of $\mathrm{BiCl}_{3}$ to the melt, a deposition/stripping peak at $1.0 \mathrm{~V}$ ( $\mathrm{vs} \mathrm{Ag} / \mathrm{AgCl}$ ), which is typical for the formation of U-Bi alloys [34], was observed in the cyclic voltammogram shown in Fig. 10 (red curve). After bubbling argon through the melt, the OCP stabilized around $-0.6 \mathrm{~V}$ (vs $\mathrm{Ag} / \mathrm{AgCl})$, and the peaks in the $\mathrm{CV}$ at - 1.0 and $0.15 \mathrm{~V}$ (vs $\mathrm{Ag} / \mathrm{AgCl}$ ) were no longer observed while a new deposition/stripping peak appeared at $-1.6 \mathrm{~V}$ (vs $\mathrm{Ag} / \mathrm{AgCl}$ ) typical of the $\mathrm{U} / \mathrm{U}^{3+}$ couple. A solublesoluble wave of relatively weak intensity was identified at $-0.4 \mathrm{~V}(\mathrm{vs} \mathrm{Ag} / \mathrm{AgCl})$ which is assigned to the $\mathrm{U}^{4+} / \mathrm{U}^{3+}$ couple [19, 34].

From these results, we can deduce that the $\mathrm{Bi}^{3+}$ in solution reacts with the uranium metal to initially form what appears to be U(IV). Since the value of the OCP of the solution is higher than the $\mathrm{U}^{3+} / \mathrm{U}^{4+}$ potential, it is thought that the uranium metal is directly oxidized to $\mathrm{U}(\mathrm{IV})$, with no evidence for the formation of any

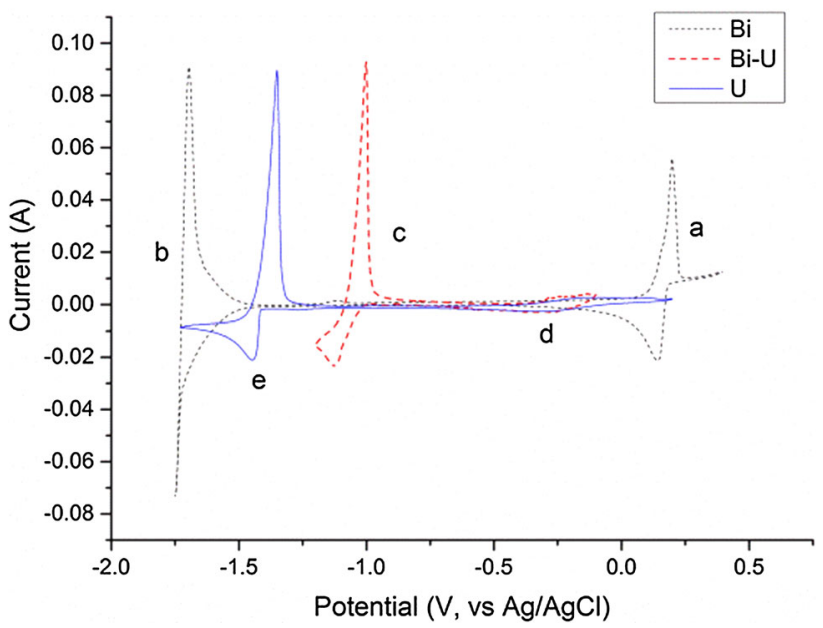

Fig. 10 Cyclic voltammograms of $\mathrm{BiCl}_{3}$ dissolved in LKE (black dashed line; Assigned redox processes-a: $\left.\mathrm{Bi} / \mathrm{Bi}^{3+}, \mathrm{b}: \mathrm{Bi}_{\mathrm{x}} \mathrm{Li}_{\mathrm{y}} / \mathrm{Bi}^{3+}\right)$, partway through the reaction of $\mathrm{BiCl}_{3}$ with excess $\mathrm{U}$ metal in LKE (red dashed line; Assigned redox process- $-\mathrm{c}$ : $\mathrm{Bi}_{\mathrm{x}} \mathrm{U}_{\mathrm{y}} / \mathrm{U}^{3+}$ ) and at completion of the reaction of $\mathrm{BiCl}_{3}$ with $\mathrm{U}$ metal in LKE (blue line; Assigned redox processes-d: $\mathrm{U}^{3+} / \mathrm{U}^{4+}$, e: $\left.\mathrm{U} / \mathrm{U}^{3+}\right)\left\{\mathrm{T}=450{ }^{\circ} \mathrm{C}\right.$; Scan rate $=0.1 \mathrm{~V} \mathrm{~s}^{-1}$; Working electrode: $\mathrm{W}$ rod; Counter electrode: $\mathrm{W}$ rod; Reference electrode: $\mathrm{Ag} / \mathrm{AgCl}$ (1.5 wt\% in LKE) \}. (Color figure online) 
significant quantities of U(III). Once the melt was bubbled with argon, the redox couples for $\mathrm{Bi} / \mathrm{Bi}^{3+}$ and uranium bismuth alloys were not observed on the CVs of the melt, indicating $\mathrm{Bi}(\mathrm{III})$ was no longer present. Meanwhile characteristic peaks for the presence of uranium in the salt were observed. The measured OCP is concordant with $\mathrm{W}$ in contact with $\mathrm{UCl}_{3}$ in $\mathrm{LiCl}-\mathrm{KCl}$ eutectic.

\section{Redox mechanism}

The results described present a clear picture of the different reactions taking place in the melt. Firstly, the $\mathrm{BiCl}_{3}$ dissolves in the $\mathrm{LiCl}-\mathrm{KCl}$ eutectic, as shown by the $\mathrm{CV}$ measurement in Fig. 8 and the OCP jump in Fig. 9, which has been identified by Volkov et al. by absorption spectroscopy as $\mathrm{BiCl}_{4}{ }^{-}$[28]. Initially, the dissolved $\mathrm{Bi}(\mathrm{III})$ reacts with the uranium metal to form U(IV) in the bulk melt as explicated in Eq. (5) and observed by OCP measurement and absorption spectroscopy (Figs. 4 and 5). Once the concentration of U(IV) in the melt is high enough it combines with the uranium metal to form U(III), as shown by the increase of the U(III) peak at $899 \mathrm{~nm}$ shown in Fig. 6. The U(III) is then oxidized to U(IV) by the $\mathrm{Bi}(\mathrm{III})$ in the bulk solution. This is in accordance with Eqs. (6) and (7) and is observed in the "smog chimney" localized presence displayed in Fig. 3.

$\mathrm{U}_{\text {metal }}+\frac{4}{3} \mathrm{Bi}_{\text {sol }}^{3+} \rightarrow \mathrm{U}_{\text {sol }}^{4+}+\frac{4}{3} \mathrm{Bi}_{\text {metal }}$

$\mathrm{U}_{\text {metal }}+3 \mathrm{U}_{\text {sol }}^{4+} \rightarrow 4 \mathrm{U}_{\text {sol }}^{3+}$

$\mathrm{U}_{\text {sol }}^{3+}+\frac{1}{3} \mathrm{Bi}_{\text {sol }}^{3+} \rightarrow \mathrm{U}_{\text {sol }}^{4+}+\frac{1}{3} \mathrm{Bi}_{\text {metal }}$

The proposed chemical processes for the oxidation of uranium metal in $\mathrm{LiCl}-\mathrm{KCl}$ eutectic by $\mathrm{BiCl}_{3}$ enables to differentiate the possible outcomes in the final melt composition as a function of the $\mathrm{BiCl}_{3} / \mathrm{U}$ metal ratio and the necessity for thorough mixing of the melt to ensure the oxidation state purity of U(III) in the melt. Indeed the formation of U(IV) as an intermediary product, calls for the presence of excess uranium metal to ensure pure U(III) in the salt solution. The possibility to obtain a mixture of U(III) and U(IV) if the conditions are not well controlled should also be considered. This can easily be verified by measuring the OCP of the solution.

\section{Conclusion}

The mechanism of the reaction of uranium metal with bismuth trichloride in $\mathrm{LiCl}-\mathrm{KCl}$ eutectic has been studied. Experimental work was conducted and monitored by in-situ electrochemical measurements, absorption spectroscopy and visual observation. It is thought that the mechanism can be described by the reactions explicated in Eq. (5-7).

It was not possible to obtain conclusive spectroscopic information at the surface of the uranium metal, so it is not possible to totally rule out the formation of U(III) as a short lived intermediate from the reaction described in Eq. (5). The formation of U(IV) as an intermediate product will prevent the use of this method for industrial purposes as has been seen for the use of $\mathrm{CuCl}_{2}$ as oxidant because of its reactivity with the metallic vessel. On the other hand, the high vapour pressure of $\mathrm{BiCl}_{3}$ and the low toxicity of the by-product makes this route a very convenient way to produce dissolved, redox-pure U(III) in $\mathrm{LiCl}-\mathrm{KCl}$ eutectic that is ideal for laboratory research purposes, as long as stoichiometry is controlled (i.e. $1: 1 \mathrm{U}_{\text {metal }}: \mathrm{Bi}^{3+}$ molar ratio) and the reaction melt is sufficiently mixed. Further work will study the kinetics of the different reactions identified and explore the effect of possible alloying reactions at the surface of the uranium metal on the reaction mechanism and the quality of the final reaction products.

Acknowledgements This work, including a studentship for HL, was performed as part of the SACSESS consortium which was financially supported by European Atomic Energy Community (EURATOM) Seventh Framework Programme under contract No. FP-Fission-2012323-282. This work was also supported by the UK Engineering and Physical Sciences Research Council (EPSRC) funded REFINE consortium (http://www.refine.eng.ed.ac.uk/). The authors also gratefully acknowledge financial support from the EPSRC (EP/J000795/1). The authors would like to acknowledge the contribution of the workshop in the School of Chemical Engineering and Analytical Science at the University of Manchester with technical designs for the electrochemical and spectroscopic cells.

Open Access This article is distributed under the terms of the Creative Commons Attribution 4.0 International License (http://creative commons.org/licenses/by/4.0/), which permits unrestricted use, distribution, and reproduction in any medium, provided you give appropriate credit to the original author(s) and the source, provide a link to the Creative Commons license, and indicate if changes were made.

\section{References}

1. Choi E-Y, Jeong SM (2015) Electrochemical processing of spent nuclear fuels: an overview of oxide reduction in pyroprocessing technology. Prog Nat Sci Mater Int 25:572-582

2. Lee HJ, Ko WI, Choi SY, Kim SK, Kim IT, Lee HS (2014) An approach to developing an integrated pyroprocessing simulator. AIP Conf Proc 1584:9-14

3. Lee H, Park G, Lee J, Kang K, Hur J, Kim J, Paek S, Kim I, Cho I (2013) Current Status of Pyroprocessing Development at KAERI. Sci Technol Nucl Install 2013:343492

4. Serp J, Allibert M, Beneš O, Delpech S, Feynberg O, Ghetta V, Heuer D, Holcomb D, Ignatiev V, Kloostermang JL, Luzzi L, Merle-Lucotte E, Jan Uhlî̃ J, Yoshioka R, Zhimin D (2014) The molten salt reactor (MSR) in generation IV: overview and perspectives. Prog Nucl Energy 77:308-319 
5. Zhimin D, Yang Z, Kun C (2016) Thorium molten salt reactors (TMSR): development in China. In: IAEA technical meeting on the status of molten salt reactor technology, Vienna, Austria

6. Rappleye DS (2013) Developing safeguards for pyroprocessing: detection of a plutonium Co-deposition on solid cathode in an electrorefiner by applying the signature-based safeguards approach. PhD Thesis. North Carolina State University, Raleigh

7. Cumberland RM, Yim M-S (2014) Development of a 1D transient electrorefiner model for pyroprocess simulation. Ann Nucl Energy 71:52-59

8. Henslee SP, Benedict RW (1997) EBR-II spent fuel treatment demonstration project. In: American Nuclear Society Winter Meeting, Albuquerque

9. Polovov IB, Volkovich VA, Charnock JM, Kralj B, Lewin RG, Kinoshita H, May I, Sharrad CA (2008) In situ spectroscopy and spectroelectrochemistry of uranium in high-temperature alkali chloride molten salts. Inorg Chem 47:7474-7482

10. Miller WE, Tomczuk Z (2004) Method for making a uranium chloride salt product. US Patent 6,800,262 B1

11. Wang CS, Liu Y, He H, Gao FX, Liu LS, Chang SW, Guo JH, Chang L, Li RX, Ouyang YG (2013) Electrochemical separation of uranium and cerium in molten $\mathrm{LiCl}-\mathrm{KCl}$. J Radioanal Nucl Chem 298:581-586

12. Edelmann FT (1997) Synthetic methods of organometallic and inorganic chemistry. In: Herrmann WA (series ed) vol 6, Thieme, New York

13. Katz JJ, Rabinowitch E (1951) The chemistry of uranium. McGraw-Hill, New York

14. Inman D, Hills GJ, Young L, Bockris JOM (1959) Electrode reactions in molten salts: the uranium + uranium trichloride system. Trans Faraday Soc 55:1904-1914

15. Li SX, Vaden D, Westphal BR, Fredrickson GL, Benedict RW, Johnson TA (2007) Integrated efficiency test for pyrochemical fuel cycles. In: GLOBAL 2007 Advanced nuclear fuel cycles and systems, Illinois

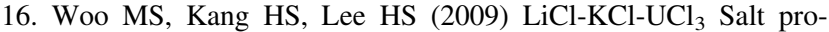
duction and transfer for the uranium electrorefining. In: Transactions of the Korean Nuclear Society Spring Meeting, Jeju

17. Westphal BR, Price JC, Mariani RD (2012) Synthesis of uranium trichloride for the pyrometallurgical processing of used nuclear fuel. In: Kongoli F (ed) Fray international symposium on molten salts and ionic liquids. Flogen Star Outreach, Quebec

18. Serp J, Konings RJM, Malmbeck R, Rebizant J, Scheppler C, Glatz J-P (2004) Electrochemical behaviour of plutonium ion in LiCl-KCl eutectic melts. J Electroanal Chem 561:143-148

19. Masset P, Bottomley D, Konings R, Malmbeck R, Rodrigues A, Serp J, Glatz J-P (2005) Electrochemistry of Uranium in Molten LiCl-KCl Eutectic. J Electrochem Soc 152:A1109-A1115
20. Masset P, Apostolidis C, Konings RJM, Malmbeck R, Rebizant J, Serp J, Glatz J-P (2007) Electrochemical behaviour of neptunium in the molten $\mathrm{LiCl}-\mathrm{KCl}$ eutectic. J Electroanal Chem 603:166-168

21. HSC Chemistry 9.0 (2017) Outotec Technologies. Orly

22. Nourry C, Soucek P, Massot L, Malmbeck R, Chamelot P, Glatz J-P (2010) Electrochemistry of uranium in molten fluorides. In: Proceedings of the First ACSEPT International Workshop. Lisbon

23. Bae S-E, Cho Y-H, Park YJ, Ahn HJ, Song K (2010) Oxidation state shift of uranium during U(III) synthesis with $\mathrm{Cd}(\mathrm{II})$ and $\mathrm{Bi}(\mathrm{III})$ in $\mathrm{LiCl}-\mathrm{KCl}$ melt. Electrochem Solid-State Lett 13:F25F27

24. Claux B (2011) Etude de la reduction electrochimique d'oxydes d'actinides en milieu sels fondus, $\mathrm{PhD}$ Thesis, Universite de Grenoble, Grenoble

25. de Vaulchier du Deschaux L, de Fouchier A, de Vaucelles E, Facquet L (1972) Surface preparation of uranium parts. US Patent $3,674,655$

26. Lambert H, Claux B, Sharrad C, Soucek P, Malmbeck R (2016) Spectroscopic studies of neodymium(III) and praseodymium(III) compounds in molten chlorides. Proc Chem 21:409-416

27. Park Y-J, Bae S-E, Cho Y-H, Kim J-Y, Song K (2011) UV-vis absorption spectroscopic study for on-line monitoring of uranium concentration in $\mathrm{LiCl}-\mathrm{KCl}$ eutectic salt. Microchem J 99:170-173

28. Volkov CV, Buryak NI, Kozin VF, Sheka IA (1991) Spectra and structure for $\mathrm{Bi}^{0}-\mathrm{BiCl}_{3}-\mathrm{Li}, \mathrm{K} / \mathrm{Cl}$. Theor Exp Chem 27:270-273

29. Merritt C, Hershenson HM, Rogers LB (1953) Spectrophotometric determination of bismuth, lead, and thallium with hydrochloric acid. Anal Chem 25:572-577

30. Cho Y-H, Bae S-E, Park Y-J, Oh S-Y, Kim J-Y, Song K (2012) Electronic Structure of U (III) and U (IV) Ions in a $\mathrm{LiCl}-\mathrm{KCl}$ eutectic melt at 450 \& \#xB0;C. Microchem J 102:18-22

31. Gruen DM, McBeth RL (1959) Oxidation states of complex ions of uranium in fused chlorides and nitrates. J Inorg Nucl Chem 9:290-301

32. Fujii $T$, Uda $T$, Fukasawa $K$, Uehara A, Sato $N$, Nagai $T$, Kinoshita K, Koyama T, Yamana H (2013) Quantitative analysis of trivalent uranium and lanthanides in a molten chloride by absorption spectrophotometry. J Radioanal Nucl Chem 296:255-259

33. Shirai O, Uozumi K, Iwai T, Arai Y (2011) Electrode reaction of the $\mathrm{U}^{3+} / \mathrm{U}$ couple at liquid $\mathrm{Cd}$ and $\mathrm{Bi}$ electrodes in $\mathrm{LiCl}-\mathrm{KCl}$ eutectic melts. Anal Sci 17:i959-i962

34. Hoover RO, Shaltry MR, Martin S, Sridharan K, Phongikaroon S (2014) Electrochemical studies and analysis of $1-10 \mathrm{wt} \% \mathrm{UCl}_{3}$ concentrations in molten $\mathrm{LiCl}-\mathrm{KCl}$ eutectic. J Nucl Mater 452:389-396 